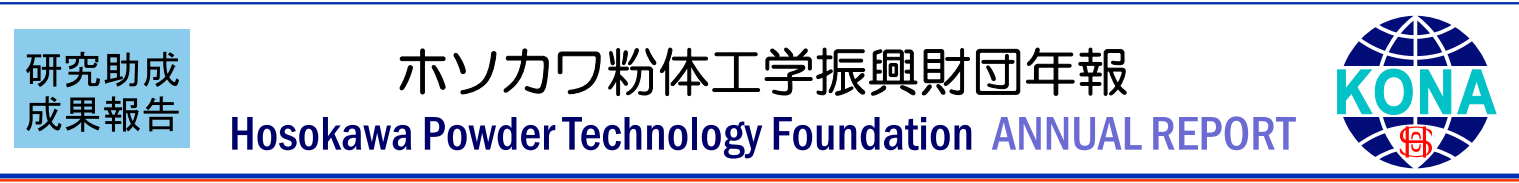

18102

\title{
ペロブスカイト型量子ドットの光劣化・自己回復の研究 \\ Investigation on Photodegradation and Self-Recovery of Perovskite Quantum Dot
}

\author{
研究代表者 Research leader：磯 由樹 Yoshiki ISO \\ 慶應義塾大学理工学部 専任講師 \\ Faculty of Science and Technology, Keio University, Assistant Professor \\ E-mail: iso@applc.keio.ac.jp
}

\begin{abstract}
抄 録
ペロブスカイト型量子ドットである $\mathrm{CsPBr}_{3}$ ナノ結晶（NC）は優れた蛍光体として近年注目され ているが, 励起光照射による劣化が問題となっている，筆者らは，大気から隔離した $\mathrm{CsPBr}_{3} \mathrm{NC}$ を光劣化させた後に暗所で保管すると, 自己回復することを見出した. 本研究では, この光劣化と 自己回復のメカニズムについて探究した. 合成した $\mathrm{CsPBr}_{3} \mathrm{NC}$ を固体試料セルに密封充填した. $468 \mathrm{~nm}$ の青色 LED $72 \mathrm{~h}$ 照射したところ, 試料が黄色から黒色に変化し, 蛍光強度が大きく低下 した。続いて暗所で保管すると試料の色が黄色に戻り，2400 h 後には完全に蛍光強度が回復した。 赤外分光法により $\mathrm{NC}$ 表面に吸着している表面リガンドを分析すると, オレイン酸の吸着状態に恋 化が見られた，光劣化の原因は，励起光照射で生成した励起子が $\mathrm{NC}$ 表面に拡散したことで吸着し ているリガンドが脱離し, 表面欠陥が生成したためと推察される. 自己回復はこの脱離したリガン ドが再吸着したことで発現したと考えられる。
\end{abstract}

\begin{abstract}
$\mathrm{CsPbBr}_{3}$ nanocrystal (NC), which is a perovskite quantum dot, has attracted much attention as excellent phosphor; however, its deterioration by excitation light is a significant problem. The authors founded selfrecovery of $\mathrm{CsPbrr}_{3} \mathrm{NC}$ during dark storage after photodegradation without ambient air. In this work, the photodegradation and self-recovery were investigated. Synthesized $\mathrm{CsPbBr}_{3} \mathrm{NC}$ was packed in a solid-sample cell. The sample color changed from yellow to black by $468 \mathrm{~nm}$ blue LED irradiation for $72 \mathrm{~h}$, accompanied with decrease in photoluminescence (PL) intensity. The color returned to yellow during subsequent dark storage, and the PL intensity recovered completely after $2400 \mathrm{~h}$. Infrared spectroscopy for surface ligand on the NC surface revealed change in adsorption state of oleic acid. The photodegradation might be explained by desorption of the surface ligand due to diffused excitons generated by the excitation irradiation. The selfrecovery should be resulted from readsorption of the desorbed ligand.
\end{abstract}




\section{研究背景と目的}

次世代型広色域ディスプレイの開発におい て, 発光ピークの半值幅が狭い蛍光材料の利用 が望ましい。半導体ナノ結晶（NC）である量 子ドットがディスプレイに応用され始めてお り，近年ではペロブスカイト型 $\mathrm{CsPbr}_{3} \mathrm{NC}$ が 注目されている（Iso Y. and Isobe T., 2018）。こ の材料は, 従来の量子ドットと比較しても発光 ピークの半值幅が狭いために色純度が極めて高 く，かつ高い蛍光量子収率を示す。しかしき な問題として, 励起光照射による劣化 (光劣化) がある．実用上，デバイスへの応用では蛍光体 に十分な耐光性が求められる。 そのため, 励起 光照射に対する安定性は重要な評価項目とな る，蛍光ナノ材料は比表面積が非常に大きいこ とから，その蛍光特性は表面状態の変化による 影響を受けやすい。 そのため, 表面の保護によ る光劣化の抑制に関する研究が多くなされてき た，そのような中で筆者は，光劣化した $\mathrm{NC}$ 自己回復を示すことを発見した。本研究では, $\mathrm{CsPbr}_{3} \mathrm{NC}$ の光劣化と自己回復のメカニズム について探究した。

\section{研 究 方 法}

\section{1. 試料の作製方法}

擋找しながら1-オクタデセン中に臭化鉛 (II)，オレイン酸抢よびオレイルアミンを加え て $180^{\circ} \mathrm{C}$ まで昇温した。これに，オレイン酸 セシウムの1-オクタデセン溶液をインジェク ションして $\mathrm{CsPbr}_{3} \mathrm{NC}$ を得た。この $\mathrm{NC}$ を遠 心分離で回収し, 真空乾燥して $\mathrm{CsPbBr}_{3} \mathrm{NC}$ 固 体試料を得た。

\section{2. 光劣化および自己回復の評価}

図1のように, 試料を固体試料ホルダーに密 閉充填し, $468 \mathrm{~nm}$ の青色励起光 $\left(48.5 \mathrm{~W} \mathrm{~m}^{-2}\right)$ を $72 \mathrm{~h}$ 連続で照射した。さらにその後, 暗所 で保管した，光照射中および暗所保管中におけ る $\mathrm{NC}$ の諸特性の変化を評価した。

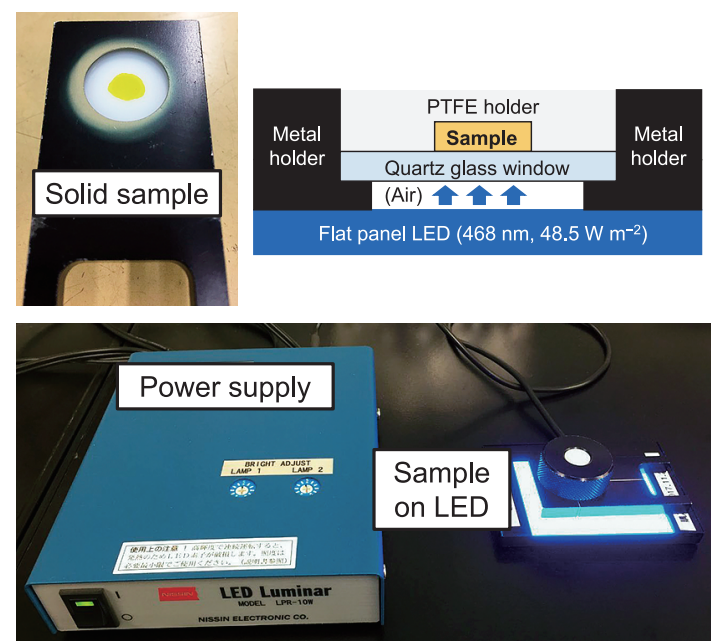

Fig. 1 Prepared solid NC sample in a sample holder and a flat panel blue LED.

研 究 成 果

\section{1. 光学特性の変化}

図 2 に光照射中と暗所保管中の試料外観の変 化を示す．光照射を $72 \mathrm{~h}$ 行うことで試料は黄 色から黒色へと変化した。ささらにその後，暗所 保管中に色が変化し，暗所保管 $2400 \mathrm{~h}$ 後には 元の黄色へと戻った。図 3 に蛍光 (PL) スペ クトルの変化を示す. 光照射を $72 \mathrm{~h}$ 行うこと でPL 強度は初期強度の $20 \%$ まで減少した。そ の後, 暗所保管中にPL 強度は徐々に増加し, 暗所保管 $2400 \mathrm{~h}$ 後には初期強度の $108 \%$ まで 回復した。

\section{2. 粒子形態の変化}

図 4 に透過型電子顕微鏡（TEM）像を示す。 四角形状のナノ粒子が観察された。合成直後の 平均粒子径は $8.4 \pm 1.7 \mathrm{~nm}$ であった。光照射 $72 \mathrm{~h}$ 後では長方形状のナノ粒子も観察された. 平均粒子径は $16.4 \pm 4.1 \mathrm{~nm}$ であり, 光照射で 粒子径の増大が見られた。光照射下で $\mathrm{CsPBr}_{3}$ $\mathrm{NC}$ から表面リガンドが光誘起脱離を起こし (Wang Y. et al., 2016)，隣接する粒子間で露出 した結晶表面同士が接合したと考えられる。こ こで光誘起脱離とは, 励起光照射下で表面リガ ンドが脱離するという他の量子ドットでも見ら 

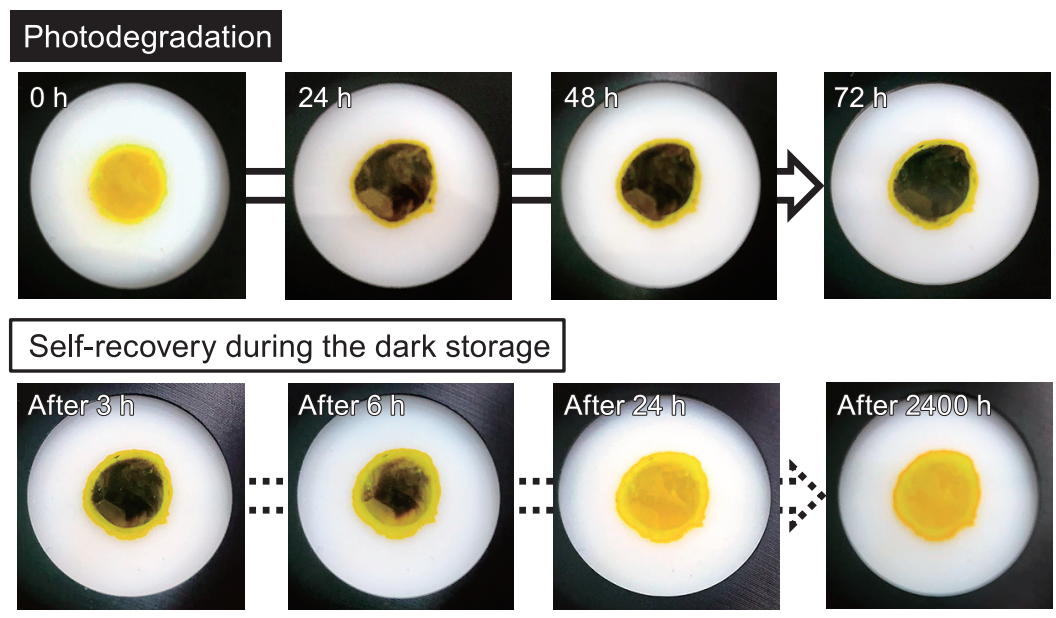

Fig. 2 Color change of $\mathrm{CsPbBr}_{3} \mathrm{NC}$ during the irradiation and subsequent dark storage.
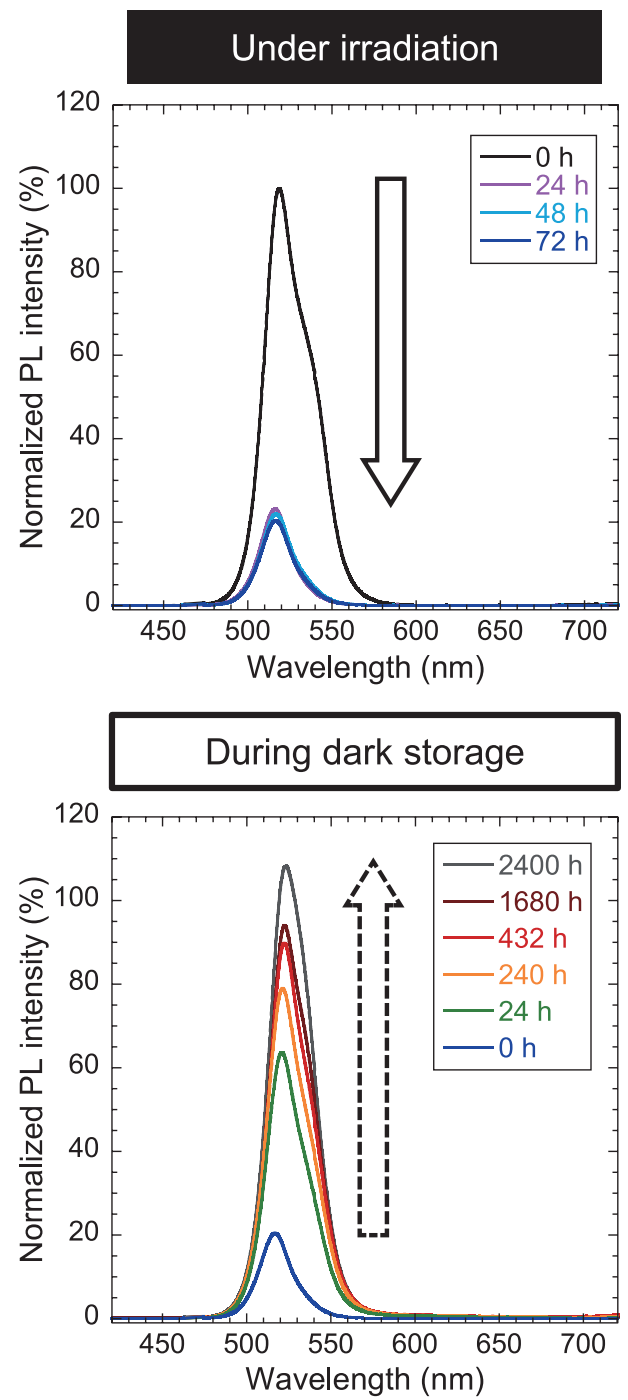

Fig. 3 Change in PL spectrum of $\mathrm{CsPbBr}_{3} \mathrm{NC}$ during the irradiation and subsequent dark storage. $\lambda_{\text {ex }}=468 \mathrm{~nm}$.
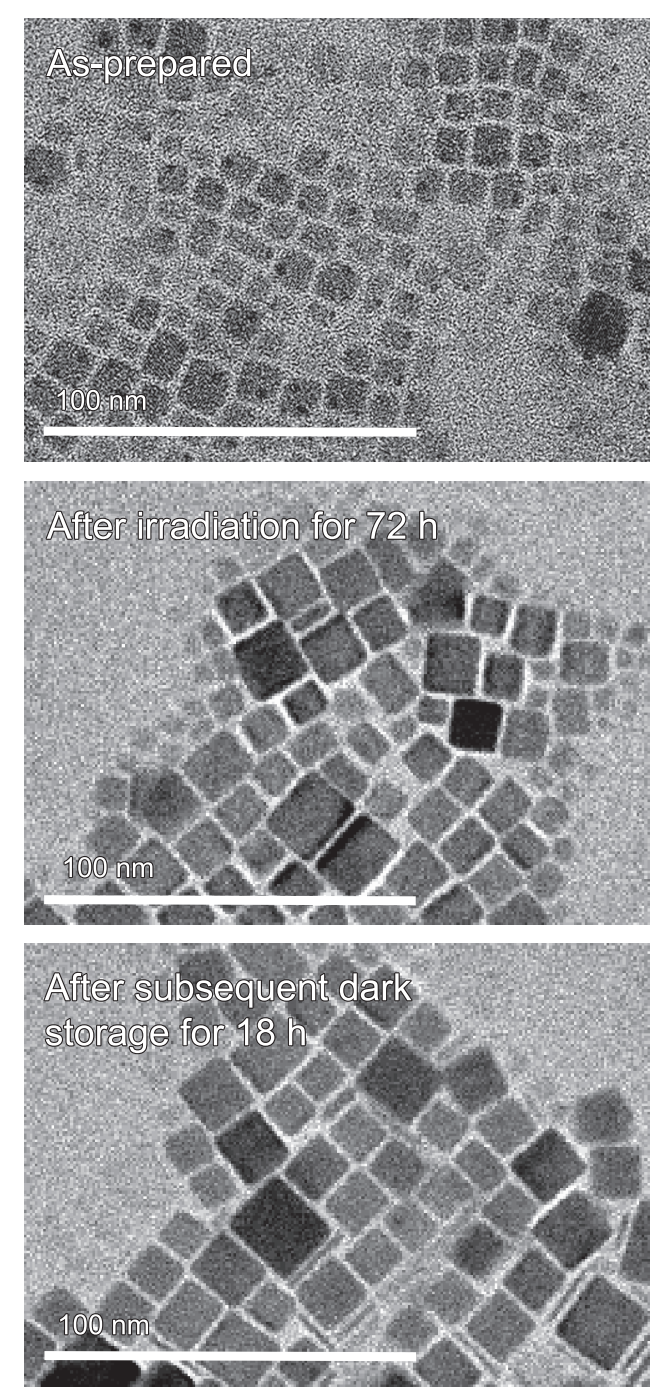

Fig. 4 TEM images of $\mathrm{CsPbBr}_{3} \mathrm{NC}$. 
れる現象である。励起光により生成された励起 子が NCの表面まで拡散すると一時的な電気的 中和が起こり，表面リガンドが脱離すると考え られる。暗所保管 $240 \mathrm{~h}$ 後の平均粒子径は $16.7 \pm 4.4 \mathrm{~nm}$ であった，光照射を終えた直後 からほとんど粒子径は変化しなかった。この結 果から，光学特性に見られた光劣化と自己回復 は粒子形態の変化による影響を受けていないと 言える。なお，X線回折法で結晶構造を評価し たところ，いずれの段階においても立方晶 $\mathrm{CsPbBr}_{3} \mathrm{NC}$ のみが検出された。結晶サイズが 増大するのみで, 結晶相の変化は見られなかっ た。

\section{3. 表面状態の分析}

図 5 に Fourier 変換赤外（FT-IR）吸収スペク トルの変化と表面リガンドの吸脱着の模式図を 示す。光照射することで $\mathrm{C}=\mathrm{O}$ の伸縮振動に帰 属されるピークが $1713 \mathrm{~cm}^{-1} に$ 新たに現れた。 これは $\mathrm{NC}$ 表面に吸着したオレイン酸の配位状 態が変化したことを示唆している。合成した粒 子の表面には脱プロトン化したオレイン酸とプ ロトン化したオレイルアミンが吸着していると 考えられる，光照射によって脱離したオリエー
卜配位子 $\left(-\mathrm{COO}^{-}\right)$は，近くのアンモニウム配 位子 $\left(-\mathrm{NH}^{3+}\right)$ からプロトンを受け取ることで オレイン酸として一時的に安定化すると考えら れる。同時に, オレイルアンモニウムは脱プロ トン化されてオレイルアミンとして存在する. 以上のような過程で粒子表面に吸着していたオ レイン酸が光誘起脱離し, オレイン酸のカルボ キシル基 (-COOH) 由来の $\mathrm{C}=\mathrm{O}$ の伸縮振動 がピークとして現れたと考えられる。その後暗 所で保管すると $\mathrm{C}=\mathrm{O}$ の伸縮振動のピーク強度 は減少した。脱離したオレイン酸が逆過程によ り再吸着したことで $\mathrm{C}=\mathrm{O}$ が消失し，ピーク強 度が減少したと考えられる。

図 6 に蛍光減衰曲線の変化を示す。得られた 曲線から蛍光寿命を求めたところ，72 h の光照 射により平均蛍光寿命は $103.9 \mathrm{~ns}$ から $13.2 \mathrm{~ns}$ まで減少した。光照射によって非放射緩和過程 による消光をもたらす表面欠陥が生成したこと を示唆する。この表面欠陉がカラーセンターと なって光照射下のペースト状 NCs 試料が黒色 化したと考えられる，光照射後の暗所保管中に 平均蛍光寿命は増大し, $240 \mathrm{~h}$ 後には $105.3 \mathrm{~ns}$ まで回復した。光照射により生成した表面欠陷 が，暗所保管中のリガンドの再吸着により消失

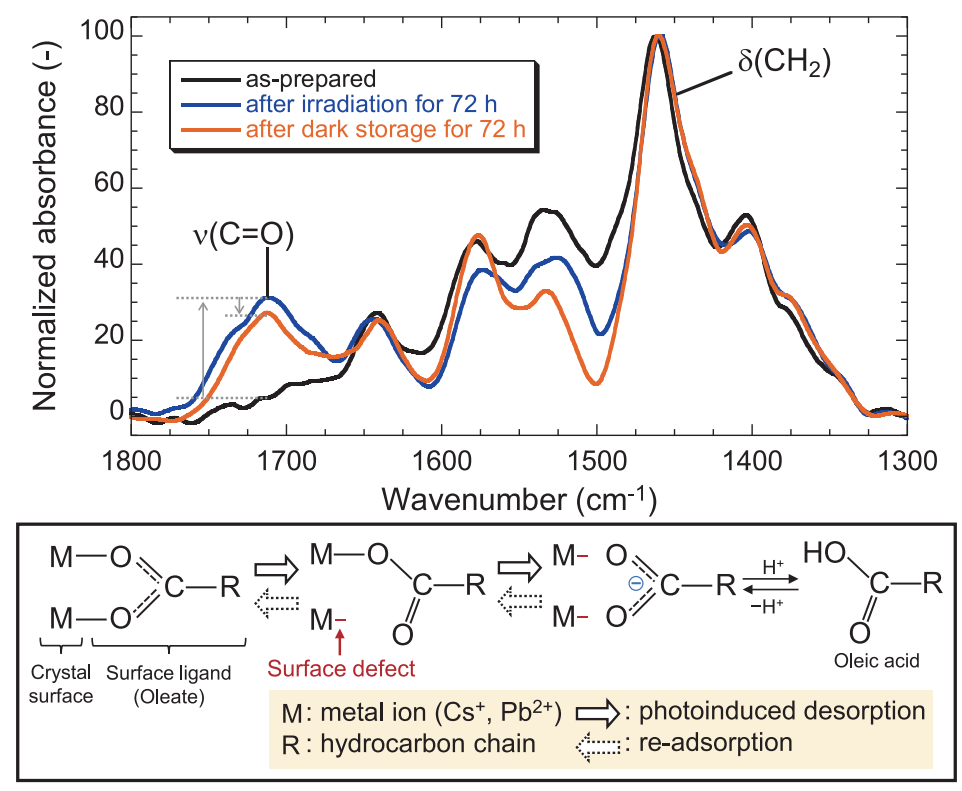

Fig. 5 Change in FT-IR spectrum of $\mathrm{CsPbBr}_{3} \mathrm{NC}$ and corresponding adsorption states of the surface ligand. 


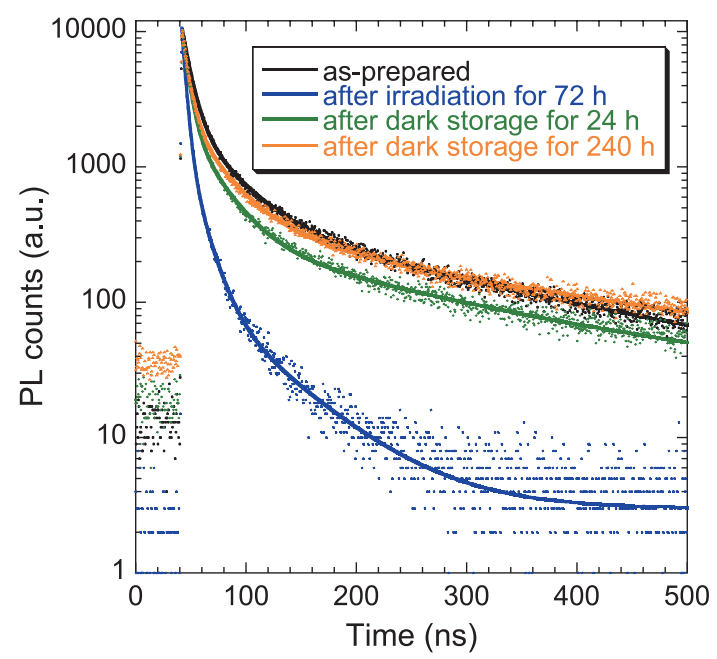

Fig. 6 Change in PL decay curve of $\mathrm{CsPbBr}_{3} \mathrm{NC}$ at $\lambda_{\mathrm{ex}}=470 \mathrm{~nm}$.

したため, 平均蛍光寿命と試料の色が元の状態 に戻ったと考えられる。

\section{4. 結論}

本研究では $\mathrm{CsPbBr}_{3} \mathrm{NC}$ が光劣化後に自己回

\section{外部 発表成果}

\section{論文発表}

1. Kidokoro K., Iso Y., Isobe T., Complete selfrecovery of photoluminescence of photodegraded cesium lead bromide quantum dots, Journal of Material Chemistry C, 7 (2019) 8546-8550. https://doi.org/10.1039/c9tc02365h

\section{口頭・ポスター発表}

1. 城所 宏次, 磯 由樹, 磯部 徹彦, “光劣化し
復する現象のメカニズムを探究した。量子ドッ トでは光誘起脱離という現象が知られており， 励起光照射により表面リガンドが脱離する。こ の光誘起脱離に伴って表面欠陥が生成し, 非輻 射緩和の確率が増大して PL 強度が低下し， か つ欠㫟準位に起因する可視光吸収の増大により 試料の色が黄色から黒色へ変化したと考えられ る。この過程は可逆的であり，表面リガンドが 再吸着して NC 表面が元の状態に戻ったために PL 特性が回復したと推察される。

\section{参考文献}

Iso Y., Isobe T., Synthesis, luminescent properties, and stabilities of cesium lead halide perovskite nanocrystals, ECS Journal of Solid State Science and Technology, 7 (2018) R3040-R3045. https://doi.org/10.1149/2.0101801jss

Wang Y., Li X., Sreejith S., Cao F., Wang Z., Stuparu M.C., Zeng H., Sun H., Photon driven transformation of cesium lead halide perovskites from few-monolayer nanoplatelets to bulk phase, Advanced Materials, 28 (2016) 10637-10643. https://doi.org/10.1002/adma.201604110

たペロブスカイト $\mathrm{CsPbBr}_{3}$ ナノ結晶の自己 回復メカニズム”, 第 80 回応用物理学会秋 季学術講演会（Sapporo, Sept. 18-21, 2019） [20p-E302-2]. <https://confit.atlas.jp/guide/ event/jsap2019a/subject/20p-E302-2/date? cryptoId $=>$

2. Kidokoro K., Iso Y., Isobe T., "Investigation on self-recovery of photodegraded perovskite $\mathrm{CsPbBr}_{3}$ nanocrystals", International Symposium on Luminescent Materials Phosphor Safari 2019 (Xiamen, China, Nov.14-17, 2019) PO-54. 